\title{
Communal roosting of Egyptian vulture Neophron percnopterus in Uttar Pradesh, India
}

\author{
Shivangi Mishra* \\ Biodiversity \& Wildlife Conservation Lab, Department of Zoology, University of Lucknow, \\ Lucknow-226007 (Uttar Pradesh), India \\ Adesh Kumar \\ Biodiversity \& Wildlife Conservation Lab, Department of Zoology, University of Lucknow, \\ Lucknow-226007 (Uttar Pradesh), India \\ ENVIS-RP, Institute for Wildlife Sciences, ONGC Center for Advanced Studies, University of \\ Lucknow, Lucknow-226007 (Uttar Pradesh), India \\ Ankit Sinha \\ Biodiversity \& Wildlife Conservation Lab, Department of Zoology, University of Lucknow, \\ Lucknow-226007 (Uttar Pradesh), India \\ Amita Kanaujia \\ Biodiversity \& Wildlife Conservation Lab, Department of Zoology, University of Lucknow, \\ Lucknow-226007 (Uttar Pradesh), India \\ \& ENVIS-RP, Institute for Wildlife Sciences, ONGC Center for Advanced Studies, University of \\ Lucknow, Lucknow-226007 ( Uttar Pradesh), India \\ *Corresponding author. Email: mishrashivangi11@gmail.com
}

\section{How to Cite}

Mishra S. et al. (2020). Communal roosting of Egyptian vulture Neophron percnopterus in Uttar Pradesh, India. Journal of Applied and Natural Science, 12(4):525 - 531. https://doi.org/10.31018/jans.v12i4.2361

\begin{abstract}
The behaviour of birds to settle or rest at a place at specific times of day and night is called roosting. Some birds prefer solitary roosting while others roost communally. The Communal roosting behaviour of Egyptian vulture was studied in five districts (Sambhal, Lakhimpur Kheri, Aligarh, Bareilly and Faizabad) of Uttar Pradesh, India from January 2014- December 2017. Total count was conducted at roosting sites in all the seasons (summer, winter and monsoon). The maximum number of individuals counted at the roost site was in Sambhal followed by Lakhimpur Kheri, Aligarh, Bareilly, Faizabad. Four different roost substrates were identified: Ground, tree, building, and electric pylon. A maximum $(63 \%)$ of Egyptian vultures were observed roosting on the ground, followed by electric pylon (19\%), tree (10\%) and minimum on building $(8 \%)$. The present study confirmed that Egyptian vultures are communal roosters and a number of roosting individuals most probably depended on the availability of food of the area. Egyptian vultures are globally endangered species and so far no work has been done on their roosting behaviour in India; therefore the present study will prove beneficial to plan for their conservation strategies.
\end{abstract}

Keywords: Communal roosting, Egyptian vulture, Roost sites, Roost substrates, food

\section{INTRODUCTION}

All birds roost but some roost solitarily while others roost communally. Roosting is a period of inactivity, such as sleep in human beings. Roosting birds usually have two key necessities: protection from predators and shelter from adversative weather. In social species, the juvenile and adult individuals generally concentrate in the form of communal roosts (Allen \& Young,1982). Egyptian vultures roost communally most often at trees (Ceballos and Donázar 1990) and near easy access to feeding sites (e.g., Donázar et al. 1997). In areas without trees, such as Fuerteventu$\mathrm{ra}$, they have been observed using electricity pylons for roosting, which depicts that accidents in power lines are the main cause of non-natural mortality (Donázar et al. 2002) as occur in other arid African regions (Levy and Mendelsohn 1989, Angelov et. al., 2012, Arkumarev et al. 2014). The plumage of these subordinate birds is often covered with bird droppings, indicating that position in the roost may incur costs in terms of reduced feather quality. The three main benefits of communal roosting are reduction in thermoregulation demands, the safety from predators and the increased foraging efficiency (Eiserer, 1984, Ydenberg, and Prins 1984). It has been studied in other raptors as Black Kites also that due to the availability 
of ample offal in rubbish dumps they have been observed roosting at some specific sites in all the seasons including monsoon (Mazumdar et al., 2016).

As very few studies like the work done by Jayson (2008) on in Kerala, and Shabnam et al., 2017a on House crow (Corvus splendens) in Gujarat are available on roosting behaviour of certain bird species in India but not on Egyptian vultures. Therefore, the protection of the areas which are continuously being used by Egyptian vultures for roosting has become a priority for the species which are globally endangered. The objective of the study was to identify the communal roost sites of Egyptian vultures, Neophron percnopterus to collect the basic information on the roosting behaviour of these vultures in some districts of Uttar Pradesh, India.

\section{MATERIALS AND METHODS}

Study area: The fieldwork was carried out in Sambhal, Lakhimpur Kheri, Aligarh, Bareilly and Faizabad district five districts of Uttar Pradesh (Fig. 1) which is the fourth largest state of India in a geographical area, situated between $23^{\circ} 52^{\prime} \mathrm{N}$ and $31^{\circ} 28^{\prime} \mathrm{N}$ latitudes and $77^{\circ} 3^{\prime}$ and $84^{\circ} 39^{\prime} \mathrm{E}$ longitudes.

Sambhal $\left(28.58^{\circ} \mathrm{N}, 78.55^{\circ} \mathrm{E}\right)$ city is famous for its unique kind of horn and bone craft items. It is a part of Moradabad division of Uttar Pradesh. There are a number of slaughterhouses running there.

Lakhimpur Kheri $\left(27.6^{\circ} \mathrm{N}, 80.34^{\circ} \mathrm{E}\right)$ is the largest district in Uttar Pradesh on the border with Nepal. Dudhwa National Park lies in this district which is the only national park in Uttar Pradesh. Kheri is a town which is around $2 \mathrm{kms}$ away from Lakhimpur.

Aligarh $\left(27.88^{\circ} \mathrm{N}, 78.08^{\circ} \mathrm{E}\right)$ is one of the largest cities along the northern area of the state. The place is famous for agricultural areas.

Bareilly $\left(28.364^{\circ} \mathrm{N}, 79.415^{\circ} \mathrm{E}\right)$ is located on the river Ramganga known for Parsakhera, a major industrial area in the district.

Faizabad $\left(26.773^{\circ} \mathrm{N}, 82.146^{\circ} \mathrm{E}\right)$ is a city situated on the banks of river Ghaghra (also known as Saryu) and is about $130 \mathrm{~km}$ east of state capital Lucknow.

Above cities were visited and searched for roosting sites of Egyptian vultures, close to potential feeding grounds, such as slaughterhouses, food industries, dumpsites Hence these areas were preferred for identification of roosting sites.

Population census: Total count of roosting individual was conducted between 2014 to 2017 in all the seasons (Winter: December-February, Summer: MarchMay and Monsoon: June-September). Seasons were categorized according to the Indian Meteorological Department (IMD) classification. Total count was done using a photographic method to avoid disturbance (Ralph and Scott, 1981), Ralph et al. (1995). Photographs were taken using a telephoto lens with a digital camera (Canon 70D and Nikon P900) from more than 500 metres. Digital images of all roosting substrates were taken for reference to enable later surveys for further work. These images were also used in the identification of tree species which were preferred for roosting.

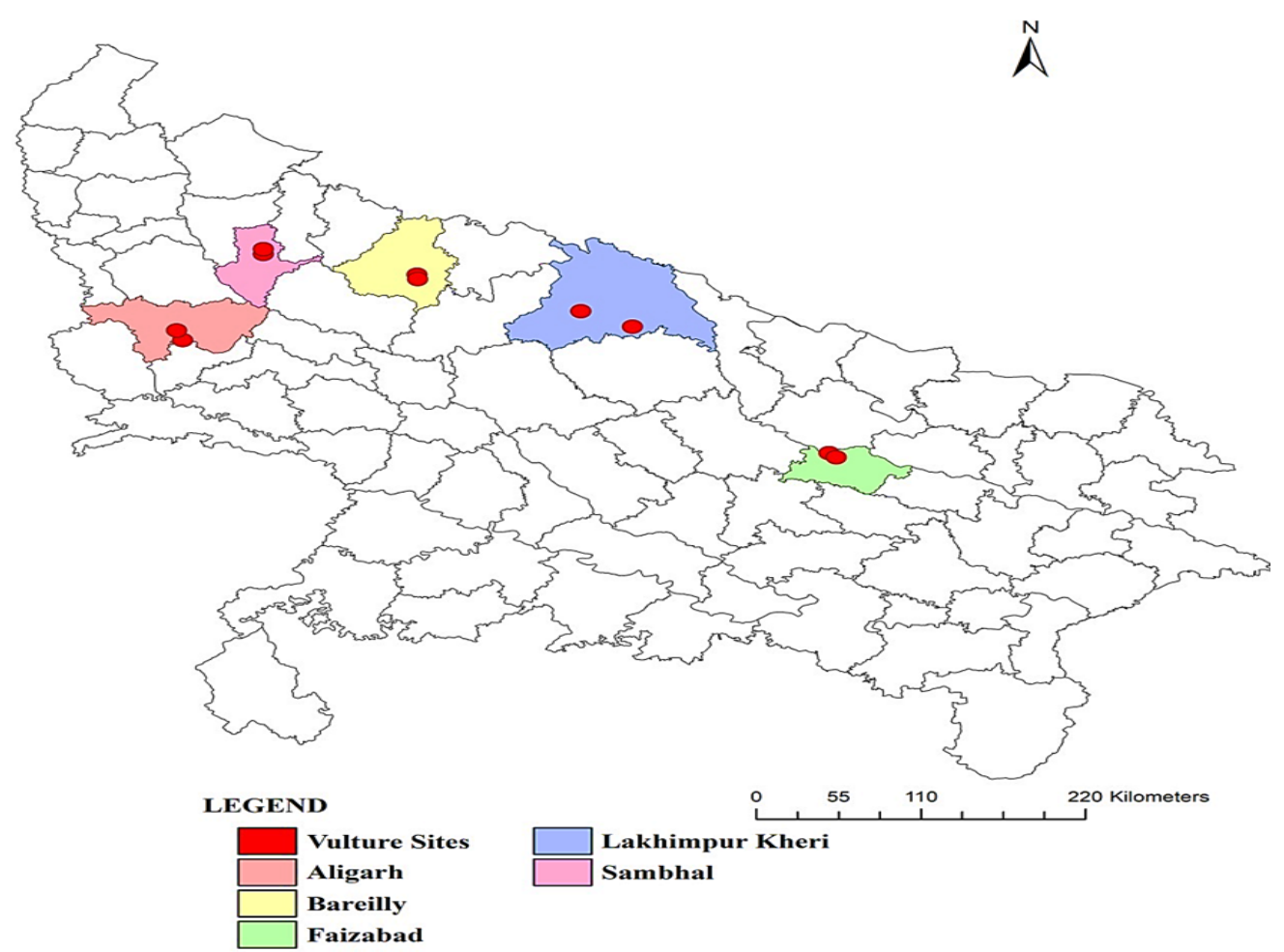

Fig.1. GIS Map of five districts of Uttar Pradesh showing the presence of communal roost sites. 


\section{RESULTS AND DISCUSSION}

Characteristics of the roosts: The number of Egyptian vultures roosting communally near the ground behind slaughterhouses, bone mill factories, dumping sites etc. and the seasons of roosting in different districts of Uttarpradesh viz. Sambhal, Aligarh, Sambhal, Lakhimpur Kheri, and Bareilly are given in Table 1.

Uttar Pradesh produces maximum buffalo meat and exports to other countries too, but now at present, a large number of illegal slaughterhouses which deal with buffalo meat and some dealing with killing cows and bullocks have been banned in Uttar Pradesh. In Sambhal and Lakhimpur-Kheri, there were a large number of legal and illegal slaughterhouses running there. Aligarh is famous for its world-class state of the art integrated modern abattoir-cum meat processing plant for producing halala meat. In district Bareilly, the dump grounds of slaughterhouses are the favourite feeding and roosting spots for Egyptian vultures. In Faizabad, the site where Egyptian vultures were observed is locally famous as "Gabbar ka Bazaar" which is basically a Cattle market, and there is a place which is surrounded by boundary where the dead cattle are thrown away, and it serves as a good feeding point for Egyptian vultures there. At all the districts the roost sites were identified near the feeding grounds. Newton (1979) studied the Communal roosts, particularly of predatory birds and scavengers, and explained it as a means of improving foraging efficiency.

The maximum and promising population of Egyptian vultures was observed at Sambhal followed by Lakhimpur Kheri, Aligarh, Bareilly, Faizabad district of Uttar Pradesh. Ground roosting has been found very commonly at the crop field near the slaughterhouses and other food and Agro-based industries. Among tree species, they usually selected tall and mature trees like Ficus religiosa-Peepal, Ficus benghalensis Linn. Banyan, Melia azedarach -Maha-neem, Azadirachta indica -Neem Eucalyptus sp., Holoptelea integrifoliaChillbill (Jungle cork). Bombax ceiba- Semal, Acacia nilotica- Desi babul, Mangifera indica-Mango, Tamarindus indica- Tamarind etc. for the safe roosting.
Sometimes they have also been observed roosting at electric pylons and buildings. The present study confirmed that Egyptian vultures are communal roosters (Fig. 2). The maximum numbers of individuals were observed roosting communally in the winter season (Table 1) The thermoregulatory benefits may be the reason for larger aggregation during the winter season.

Wynne-Edwards (1962) studied about the behaviours of birds, particularly on Starlings, before their occupation of communal roosts and hypothesized that roosting behaviour to have a function of population size regulation according to the food supply. Zahavi (1970) explained about the pre-roosting gathering and the communal roosting in details. Ward and Zahavi (1973) inferred about the roosting of birds like the "information centre" for food search, whereas Erwin (1983) propounded that food location might not enhance through any information exchanged at the colony, but it takes place through the local enhancement. Communal roosting among birds has some significant values. Various scientists had a considerable discussion on the functional significance of communal roosting; different suggestions and hypothesis have been put before, few of the major hypotheses have been discussed here.

Some of the hypotheses are as follows:

Anti-predatory role: Communal roosting enables birds to protect themselves from danger. Mixed roosting strongly suggests the notion of control of predation being an important function of communal roosting (Gadgil, 1975; Elgar, 1989). Communal roost behaviour empowers the birds to decrease the risk of predation and set out as an anti-predatory function (Gadgil, 1975; Gadgil and Ali, 1975; Bertram, 1978; Pulliam, 1973; Khera and Kalsi, 1986, Subramanian et al., 2001).

Thermoregulation: Communal roost reduces the loss of heat in cold weather (Counsilman, 1974; Vasundriya et al., 2011). The presence of nearby associates in communal roost helps to reduce the energetic demands for thermoregulation through different mechanisms such as huddling and reduction. The physical

Table 1. Showing details of the communal roost sites reported in different districts of Uttar Pradesh.

\begin{tabular}{lllll}
\hline S. No. & Location & $\begin{array}{l}\text { Number of } \\
\text { Individuals of } \\
\text { Egyptian Vulture }\end{array}$ & Roosting substrate & Season \\
\hline 1. & Aligarh & $13.75 \pm 0.75$ & Farmland, Tree & $\begin{array}{l}\text { Summer } \\
\text { (March-May) } \\
\text { Winter } \\
\text { (December-February) }\end{array}$ \\
2. & Lakhimpur Kheri & $15.8 \pm 2.6$ & Electric pylon, Brick kiln & $\begin{array}{l}\text { Summer (March-May) } \\
\text { 3. }\end{array}$ \\
4. & Faizabad & $11.25 \pm 5.5$ & Ground, Building & $\begin{array}{l}\text { Monsoon } \\
\text { (June-September) } \\
\text { Winter }\end{array}$ \\
5. & Sareilly & $13.25 \pm 1.50$ & Dump Ground, Building & (December-February) \\
\hline
\end{tabular}


Mishra S. et al. / J. Appl. \& Nat. Sci. 12(4): 525 - 531 (2020)

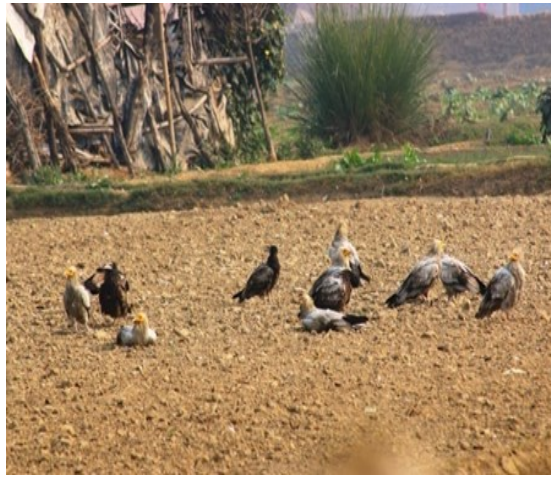

A. Ground roosting at Aligarh.

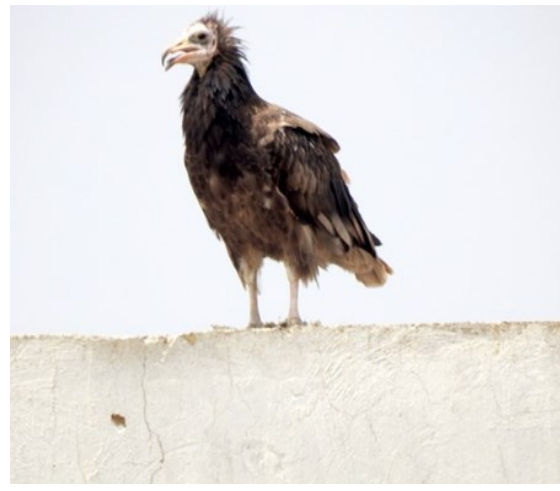

D. Juvenile roosting on a boundary of slaughterhouse, Lakhimpur Kheri.

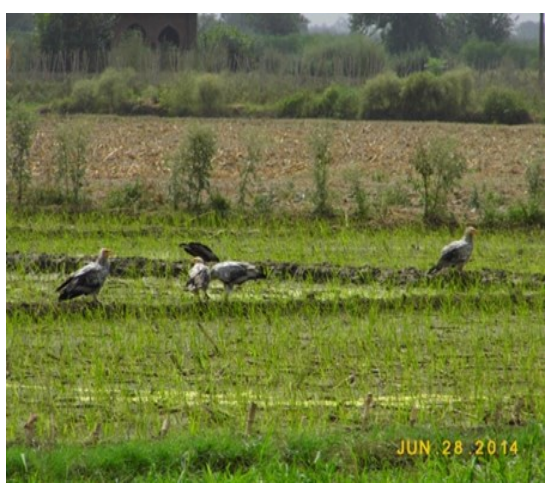

G. Roosting at an irrigated farmland, Sambhal.

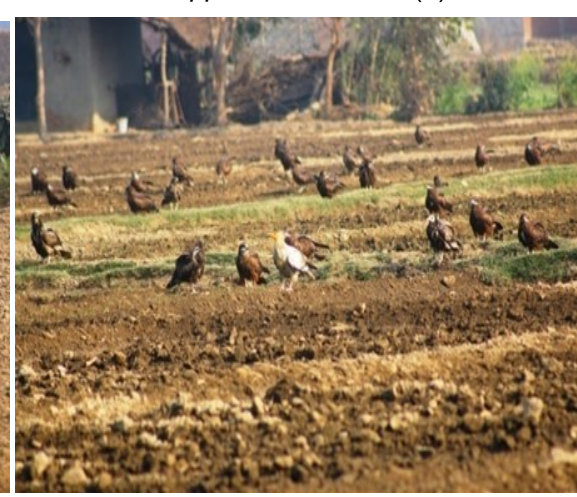

B. Roosting along with juveniles of black kite, Aligarh.

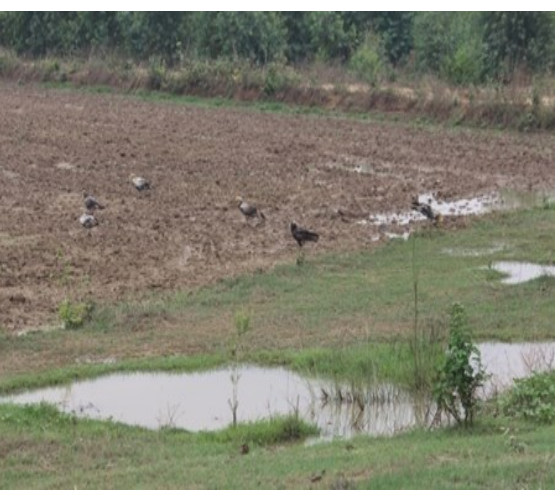

E. Ground roosting ,Bareilly.

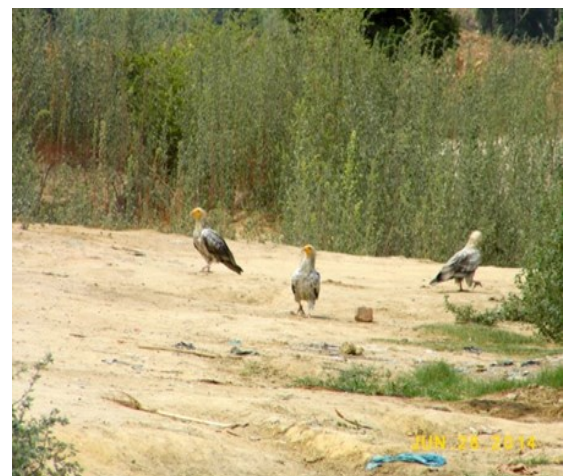

H. Ground roosting, Sambhal

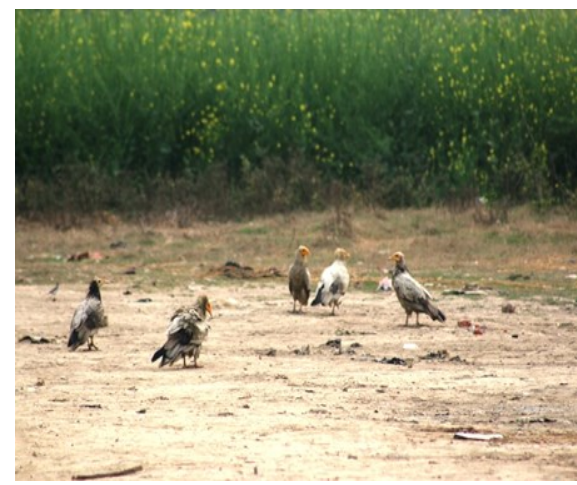

J. Roosting on ground behind cattle market, Faizabad.

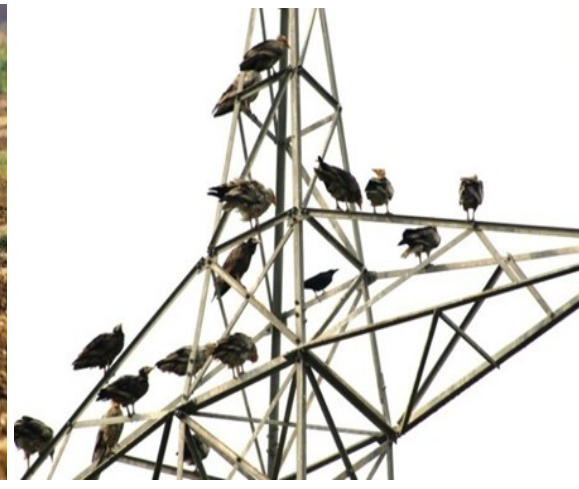

C. Adults and juveniles roosting on electric pylon, Lakhimpur Kheri.

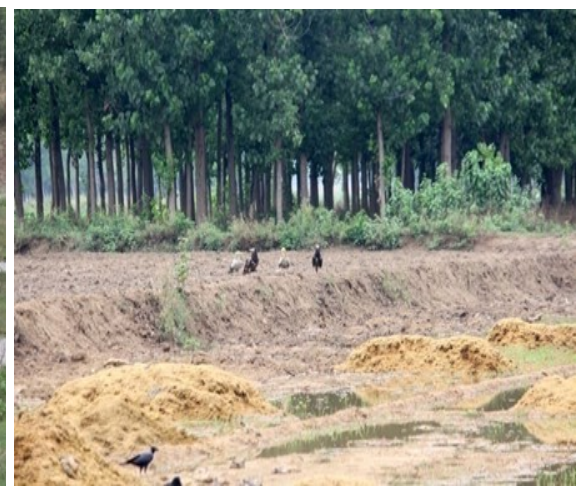

F. Ground roosting at farmland, Bareilly.

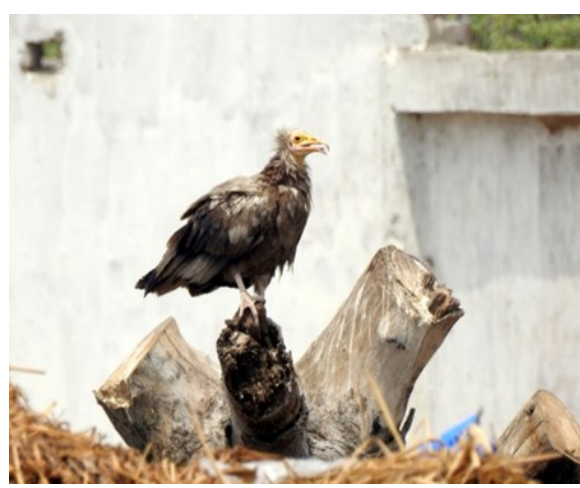

I. Subadult roosting on a dead tree, Faizabad

Fig. 2. (A-H). Showing the communal roosting sites of Egyptian vultures in few districts of Uttar Pradesh. 
structure of the roost can impart protection from adverse weather. It has also been suggested that thermoregulation benefits also increase from the presence of associates (Walsberg and King, 1980).

Social benefits: The mating and Pair formation have also observed in our study tenure during the pre-roost gathering. Mating during pre-roosting depicts one of the roles of flock gathering in the pair formation as well as affecting the strength of bonding for the next breeding season (Vyas, 1996). Braestrup (1963) suggested that the main survival value of communal roosts consists of decreased mortality during the night. It does not mean that communal roost has no social significance. Probably the communal roosting behaviour helped in contemporizing various activities within the social behaviour (Tast and Rassi, 1973; Gyllin and Kallander, 1976). Some scientists studied various systematic and synchronized behavioural patterns observed in Mynas. It was then suggested that the communal roost has some social significance. (Mahabal and Vaidya, 1989; Mahabal, 1993 a and b). Foraging efficiency: In the studies performed by various scientists, maximum roosts are situated near by an aquatic habitat and some are located nearby foraging ground. The major advantage of communal roosting in birds is enhanced foraging efficiency (Richner and Hebb, 1996; Mock et al., 1988). Communal roost points act as Information Centre where by unsuccessful foragers can follow the more companions that are successful to good foraging area (Ward and Zahavi, 1973). Communal roosting has evolved as a way of distributing information about food allocation. Weatherhead (1983) observed that successful foragers return back to the roost to get protection from predators by establishing an apt central roost position defended from predations by the surrounding individuals. Communal roosts act as an information center for the exchange of information regarding the location of food and have been evolved for the structured exploitation of patchily distributed food sources. This theory was also supported by (Gadgil and Ali, 1975 and GregSmith, 1982).

Population regulation: Communal roosting helps to assess the food supply, population density, thorough movement or regulation of reproductive rates. This hypothesis was initiated by Wynne-Edwards (1962). Some scientists have opposed this hypothesis, indicated that it is inconsistent with the principle of natural selection.

On the basis of above hypotheses, it is inferred that there is an importance of communal roosting among birds; therefore, the present study was designed to identify the main roost sites and roost substrates of Egyptian vultures at different sites. The drastic reduction in the population of these scavenger bird populations can have serious socio-economic, cultural and biodiversity impacts (Markandya et al. 2008). Four different roost substrates were characterized: Ground,

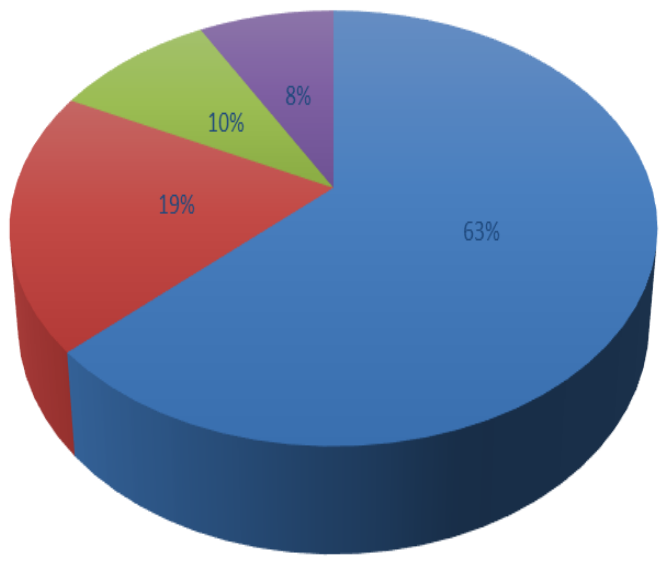

-Ground Electricpylon Tree Building

Fig. 3. Showing percentage of average number of individuals at different roost substrates during the study period.

tree, building, and electric pylon. Maximum numbers of Egyptian vultures were observed roosting on the ground $(63 \%)$, followed by electric pylon $(19 \%)$, tree $(10 \%)$ and minimum on building (8\%) (Fig.3). These roosting substrates were utilized in all the seasons during the study period. Safety was found as an important factor for selecting the roosting substrate selection.

Egyptian vultures are highly selective in choosing their roost sites; they always select the sites which are in close proximity to the food sources and waterbody to reduce the cost of movement. Among trees, they preferably select the dead trees (Ceballos and Donazar1990; Tella 1991). It has been proved that the vultures may repeatedly be attracted to a site due to the availability of a stable food supply and the proper disposal of dead livestock and that, the removal of other human-made foods may reduce vulture use of some areas. (Michael and Martin, 2016). Understanding the Communal roosting dynamics is an important factor which has been considered to reduce the human vulture conflicts in many areas like as reported in a study on Black vulture in urban areas of central amazon (Novaes and Cintra, 2013).

In the present study, all the roosts were found close to the food source (less than $4 \mathrm{~km}$ ). At almost all the study areas, it was found that Egyptian vultures actively selected their roost sites close to the slaughterhouses, dumpsites or where there is carcass availability.

\section{Conclusion}

The study will assist the management of a healthy vulture population as Egyptian vultures are globally endangered species but present in the Uttar Pradesh state of India and there are some of the districts where vultures still exist in large number and illustrates the capability of Egyptian vultures to utilize different roost substrates, as well as point out the importance of 
roosting sites. Apart from these, all the roost sites were observed at the places which were quiet and far from human settlements with negligible human interference. Egyptian vultures are social birds and were very often seen roosting and feeding with other species like house crow, black kites and cattle egrets etc. From the year 2014 to 2017 they used the same roost sites and at all the areas the trophic resources were found constant in all the seasons. The application of measures for the management of roost sites may constitute an effective conservation tool for the conservation of these globally endangered species. It is therefore urgent to consider that Egyptian vultures play an important role as cleaners of Nature.

\section{ACKNOWLEDGEMENTS}

Authors are thankful to the Head, Department of Zoology, University of Lucknow, for providing infrastructural facilities and encouragement to carry out research, Basic Scientific Research Fellowship, University Grants Commission for the financial support, we also thank the Principal Chief Conservator of Forests, Wildlife Uttar Pradesh for providing permission in the study area. Uttar Pradesh Forest Department and Volunteers Shivam Mishra, Jitendra Kumar, Vandana Dhiman, Sanjeev Upmanyu, Priya Upmanyu, Deepanshu Upmanyu for their assistance during field observations.

\section{Conflict of interest}

The authors declare that they have no conflict of interest.

\section{REFERENCES}

1. Allen, H. L., and Young L.S. (1982). An annotated bibliography of avian communal roosting. Washington State Game Department, Olympia. Washington.

2. Angelov I, Hashim I, Oppel S. (2012). Persistent electrocution mortality of Egyptian vultures Neophron percnopterus over 28 years in East Africa. Bird Conservation International 23: 1-6.

3. Bertram, B. C. R. (1978). Living in groups: predators and prey. In: Behavioural ecology: an evolutionary approach (Eds. By J. R. Krebs and N. B. Davies), Pp. 221- 248, Blackwell Scientific Publication Oxford.

4. Braestrup, E. W. (1963). The functions of Communa display, Dunsk Ornitho. Foren. Tidsskr. 57: 133-142.

5. Ceballos, O. \&Donázar, J. A. (1990). Roost-Tree Characteristics, Food Habits and Seasonal Abundance of Roosting Egyptian vultures in northern Spain. - The Raptor Research Foundation. 24(1-2): 19-25.

6. Cousilman, J. J. (1974). Breeding biology of the Indian Myna in city and aviary, 4. Notornis 21: 318-333.

7. Donázar, J. A., Naveso, M. A., Tela, J. L. and Campeón, D. (1997). (eds. Pain, D. I. \&Pienkowski, M.W.). - Farming and birds in Europe. Extensive grazing and raptors in Spain. Chapter 5,117-149.

8. Donázar, J. A., Palacios, C. J., Gangoso, L., Ceballos, O., González, M. J., Hiraldo, F. (2002). Conservation status and limiting factors in the endangered population of Egyptian Vulture (Neophron percnopterus) in the Ca- nary Islands. - BiologicalConservation, 107: 89-97.

9. Eiserer, 1984. Communal roosting in Birds. Birds Behav., 5:61-80

10.Elgar, M. A. (1989). Predator vigilance and group size in mammals and birds, Biol. Rev. 64: 13-33.

11.Erwin, R. M. (1983). Feeding habits of nesting wading birds: spatial use and social influences, Auk 100: 960970.

12.Gadgil, M. and S. Ali (1975). Communal roosting habits of Indian birds, J. Bombay Natural History Society 72 (3) 716-727.

13.Gadgil, M. (1975). The function of communal roost: relevance of mixed roosts. Ibis 9. 114: 531-533.

14. Greig-Smith, P. (1982). Behaviour of Birds Entering and Leaving Communal Roosts of Madagascar Fodies Foudia - Madagascariensis and Indian Myna Acridotheres tristis, Ibis 124 (4): 529-534.

15.Gyllin, R. and H. Kallander, (1976). Roosting behaviour of Jackdaw Corvus monedula, at Orebro, Central Sweden, Ornis. Scand 7: 113-125.

16.Jayson,E.A.(2008). Factors affecting roosting ecology of birds in Kerala,India. Technical report. DOI: 10.13140/ RG.2.2.16637.87521.

17.Khera, S. and R. S. Kalsi (1986). Waking and roosting behaviour of Bank Myna Acridotheres ginginianus, in Chandigarh and surrounding areas, Pavo 24(1\&2): 5568.

18.Levy N, Mendelssohn H. 1989. Egyptian vultures: feeding behavior. Israel Land and Nature 14: 126-131.

19. Mahabal, A. (1993a). Seasonal changes in the flocking behaviour of Indian Mynas 20. Acridotheres tristis (Linnaeus), Biovigyanam 19(1 \& 2): 55-64. 21.

20.Mahabal, A. (1993b). Communal display behaviour of Indian Myna, Acridotheres tristis (Linnaeus), Pavo 31(12): 45-54.

21.Mahabal, A. and V. G. Vaidya (1989). Diurnal Rhythmus and seasonal changes in the roosting behaviour of Indian Myna Acridotheres tristis (Linnaeus), Proceeding of Indian Academy of Science, Anim. Scie. 98(3): 199-210. 19.

22.Mazumdar, S. Ghose, D. Saha, G. K. (2016) Foraging strategies of black kites (Milvus migrans govinda) in urban garbage dumps. J Ethol 34(3):243-247.

23.Markandya, A.; T. Taylor; A. Longo \& M. Murty (2008). Counting the cost of vulture decline - An appraisal of the human health and other benefits of vultures in India. Ecological Economics 67: 194-204. doi:10.1016/j.ecolecon.20 08.04.020.

24.Michael, L. Avery and Martin, S. Lowney (2016). Vultures. Wildlife Damage Management Technical series.University of Nebraska, Lincoln .10-2016.Mock, D. W., T. C. Lamey and D. B. A. Thompso (1988). Falsifiability and the information center hypothesis, Ornis Scand 19: 231-248.

25.Novaes, W. G., and R. Cintra (2013). Factors influencing the selection of communal roost sites by the Black Vulture Coragyps atratus (Aves: Cathartidae) in an urban area in Central Amazon. Zoologia 30:607-614.

26. Newton, I. (1979). Population ecology of raptors. Poyser, London

27.Pullium, H. R. (1973). On the advantage of flocking, J. Theor. Biol., 38: 419-422.

28.Ralph, C.J. and Scott, M. (1981). Estimating numbers of terrestrial birds. Studies in Avian Biology No. 6. Cooper Ornithological Society, USA.

29.Ralph, C.J. Sauer, J.R., and Droege, S. (1995). Monitoring Bird Populations by Point Counts. 
www.rsl.psw.fs.fed.us/projects/wild/gtr149/gtr 149.html.

30.Richner, H. and P. Hebb (1996). Communal life: honest signalling and the recruitment center hypothesis, Behaviour Ecol. 7: 115-118.

31.Saiyad Shabanam, V.C. Soni and Bhupat Radadia 2017 a. A roosting site selection by Indian House Crow (Corvus splendens). International Journal of Fauna and Biological Studies, 4 (3): 10-13.

32.Subramanian, K. S. and C. J. Mathew (2001). Roosting and nesting habits of free-ranging Indian Peafowl (Pavo cristatus) in Southern Tamil Nadu, Zoo's Print Journal 16 (7): 537-538.

33.Tast, J. and P. Rassi (1973). Roosts and roosting flight of wintering Jackdaws Corvus monedula at Tampere, Finland, Ornis Fennica 50(1): 29-45.

34.Tella, J. L. (1991). Estudiopreliminar de la alimentacióndelAlimoche (Neophron percnopterus) en el Valle Medio del Ebro. - Congresolnternacional de Aves Carroeras. (ed. ICONA), 53-68.

35.Vasundriya, R. R., R . Gohel, S. Ishaque, and P. Chaudhary (2011). Roosting behaviour of Rosy Pastor Sternus roseous: a case study, Jour. of Envir. Res. and Develo. 5: 4, 920-926.

36.Volen Arkumarev, Vladimir Dobrev, Yilma D Abebe,
Georgi Popgeorgiev \& Stoyan C Nikolov (2014) . Congregations of wintering Egyptian Vultures Neophron percnopterus in Afar, Ethiopia: present status and implications for conservation, Ostrich, 85:2, 139-145, DOI: 10.2989/00306 525.2014.971450.

37.Vyas, S. N. (1996). Studies on some aspects of the ecology of Indian Black Ibis (Pseudibis papillosa) (Temminick) at Rajkot, Ph.D. Thesis, Saurashtra University, Rajkot, India.

38.Walsberg, G. E. and J. R. King (1980). The thermoregulatory significance of winter roost-sites selected by Robins in eastern Washington, Wilson Bull 92: 33-39

39.Ward, P. and A. Zahavi (1973). The importance of certain assemblages of birds as 37 . "Information centers" for food -finding, Ibis 115, 517-534.

40.Weatherhead, P. J. (1983). Two principal strategies in avian communal roosts, Am. Nat. 121: 237-243

41.Wynne-Edwards, V. C. (1962). Animal Dispersion in Relation to Social Behavior. Pp. 653, pl. 11. Edinburgh: Oliver \& Boyd. 55s

42.Ydenberg and Prins (1984). Why do birds roost communally in winter? In: Coastal waders and wildfoul in winter. Cambridge: Cambridge University Press; 123-139.

43.Zahavi, A. (1970). The functions of pre roosting gathering communal roosts, Ibis 113: 106-109 